\title{
Make art not war: defence sites find new life as centres of creativity
}

\author{
C. Clark \\ Wessex Institute of Technology, UK
}

\begin{abstract}
"And they shall beat their swords into ploughshares...." Defence sites once dedicated to national security are being transformed by artistic activity, via rededication of whole sites, conversion of individual military buildings, the construction of new galleries in former defence enclaves, temporary installations, festivals and arts events. Their transformation may or may not make reference to their military former roles and symbolic values; new enthusiasts for their history sometimes stimulate additional legislative protection for their historic value. The catalysts for these radical transformations are individual artists, sponsors or local interest groups - and sometimes the owners, the state. Barracks may become sites for reconciliation. Initiated by artists, a key event in the history of American art took place in a New York Armoury. Cultural facilities may leaven otherwise commercial redevelopments, or co-exist with continuing military functions.

The Biennales of Art and Architecture in Venice Arsenale are perhaps the grandest exemplars of the regenerative powers of art. Elsewhere, ropewalks and naval prisons become cells for practising music; workshops and chapels become concert halls; barracks are reoccupied as art schools and universities; films are made in these specialist locations; storage buildings, workshops and armouries are transformed into art galleries

Art - in its many forms - reanimates and regenerates many military sites whose primary purpose has ceased. It contributes creatively to the search to find sustainable new uses for these very special sites.
\end{abstract}

Keywords: artists, art galleries, film, music, armouries, roperies, transformation.

\section{Introduction}

'War shapes lives': proclaimed the 2002 brochure which launched the Imperial War Museum North, in Salford UK. As Greg Ashworth points out in War and the 
City [1], war has also shaped the form and development of towns and cities. Just as art was used to heal the war wounds of 6,000 amputees in Brighton's Pavilion Hospital for Limbless Soldiers from April 1916 to 1920 [2], now it's our turn to reshape redundant war dominated sites, into new, hopefully peaceful purposes.

There's nothing new about transforming war engines into peaceful production. After World War One Krupp's heavy gun factories were converted to build trams; Armstrong's works in Newcastle built cars; Bolton and Paul's aircraft factories turned out prefabs for the war displaced and Short's in Rochester resorted to the temporary building of buses. However, as bases set up for national aggression or defence become redundant, some are transformed into places of inspiration, creativity and learning. While war factories can revert to their first purpose, we may dare to hope that military sites' reinvention is permanent, while their symbolic value is not destroyed.

\section{Venice Arsenale}

In Venice the Italian state - in the form of the local heritage and environment agency and the navy - is gradually restoring the Arsenale's fragile "capanoni" (workshops in Venetian), the Gaggiandre (wet dock), mast tower, mould loft, artilleria (artillery store), roperies and basins, and finding new uses for them; since 2013 the municipality has also played an increasing role. Arts and research are the dominant new uses, but without any on-site celebration or interpretation of the Arsenale's seminal importance to the history of the republic, much symbolic value is lost. Ten years ago the navy began to convert the monumental mould loft, the Squadratori. But after repairing the roof, funds to finish the conversion still need to be found. The Istituto di Studi Militari Marittimi (Naval Staff College) is in the Palazzo San Martino inside the Porta di Terra, which also houses the navy's history library. The eastern end of the Corderie was converted into a lecture theatre used by outside organisations for conferences. From 2008 a reconstruction of the state barge, the Bucintoro, destroyed by Napoleon in 1798, was started in a canalside covered slip [3]. In 2013 France donated 600 oak trees for it. An offshoot of the university and local marine industry: Thetis, which is focused on underwater and coastal research and the impact of climate change has restored a capanone and foundry on the north side of the basin for its laboratory. It is the centre of an international network for development of coastal best practices [4].

On 6th February 2013 the government in the form of the Navy (Demanio Militare) and Venice Municipality reached agreement over the ownership of the Arsenale. The city now controls $70 \%$ of the area of the base, while the navy retained the oldest part and the basins [5]. The alternating Biennales of Art and Architecture which began in the Giardini with its permanent national pavilions have gradually colonised more and more of the Arsenale buildings - as we will see during this conference. The first art Biennale was held in 1895; after a sixyear break during World War II, it was resumed in 1948, showing avant-garde art from across the world. After the Istituto di Studi Militari Marittimi moved from Livorno to the Arsenale, in 1999-2004 Admiral Pagnottella set up the Ufficio Progetto Arsenale (Arsenal project office) with a plan to move the Museo Storico 
Navale di Venezia from the nearby Riva S. Biasio to the capanoni, redisplaying and interpreting the artefacts and adding the many artworks scattered around Italy, with university research laboratories. The restored Squadratori was to house the Istituto di Studi Militari Marittimi and to host international maritime conferences. But this proposal needed backing from the state.

Instead, arts and exhibition activity has taken over more and more of the Arsenale buildings. In the areas conceded by the Demanio Militare 50,000 square metres $(25,000$ of which is indoor space) in the southeast area have become permanent sites for Biennale activities. The Corderie, Artiglierie, Gaggiandre, Tese Cinquecentesche, Tese delle Vergini are used as exhibition spaces. Live performances take place in the Teatro alle Tese and the Teatro Piccolo Arsenale. More recently seven covered slips and the impressive mast tower are offered for hire by Hellovenezia - for exhibitions, arts performances and social events [8]. Carefully restored and converted, they provide up-to-date services for visitors: ticket-offices, bookshops, catering services, control rooms. The new Padiglione Italia, destined to the exhibitions promoted by the Ministry for Cultural Affairs, overlooks the Gaggiandre and the 16th century Tese on one side, and the Giardino delle Vergini on the other. It hosts Italian artists in a significantly enlarged structure. In 2009 the exhibition space was extended from 800 to 1800 square metres, and in 2011 a new entrance was opened from the Ponte dei Pensieri, linking the two Biennale sites: the Giardino delle Vergini and the Arsenale in the Castello district together [9]. What should be borne in mind are the implications of these initiatives to increase visitor numbers: that they cause serious problems for locals. A considerable downside of tourism for Venice is that over 300,000 visitors attend the Biennales each year, but the pressure of 60,000 tourists a day more than the entire population of the city - is damaging the quality of life for residents [10].

\section{Marfa Texas}

From 1971 minimalist artist Donald Judd transformed the small Chihuahua desert town of Marfa in Texas into a key centre for contemporary artists and craftspeople. The town was once a water stop for railway locomotives. The Marfa Army Airfield was where several thousand pilots were trained during World War II before it closed in 1945. The base was also used as the training ground for many of the United States Army's chemical mortar battalions. The spaces the airforce buildings offered were what attracted Judd to move from New York. He chose Marfa because it was far away from any major town as you can get [11]. He bought two large hangars and smaller buildings to house his large-scale work. He later acquired the decommissioned Fort D. A. Russell, once a prisoner of war camp whose murals have been preserved, where he installed permanent exhibitions of artists' work, as a kind of anti-museum, because galleries only show art for short periods of time. Since his death in 1994 the Chinati Foundation and Judd Foundation maintain his legacy. From 1997 Open House attracted thousands of visitors. The Chinati Foundation now occupies more than ten buildings at the site and shows on permanent exhibition work by artists such as Ingólfur Arnarson, Dan 
Flavin, and Claes Oldenburg. Artists and writers move to Marfa to live and work, stimulating the opening of new gallery spaces downtown and literary festivals. The desert setting has appeared in several films: There Will Be Blood, an adaptation of the Upton Sinclair novel Oil! directed by Paul Thomas Anderson and the Coen Brothers' adaptation of the Cormac McCarthy novel No Country for Old Men [9]. It also features in music videos: Edward Sharpe and the Magnetic Zeros, Between the Buried and Me, and Diamond Rings. The International Woman's Foundation nominated Fort D.A. Russell on the National Register of Historic Places in order to preserve the historic importance of the site [13].

\section{New York Armouries as art galleries}

The vast spaces of American National Guard armouries, once used to drill troops, have the capacity to attract arts activities. Two in New York are important historically and architecturally. The 69th Regiment Armory on Lexington Avenue between 25th and 26th Streets was host to the key 1913 International Exhibition of Modern Art organized by the Association of American Painters and Sculptors. It housed the first large exhibition of modern art in America, introducing astonished Americans, used to realistic art, to the experimental styles of the European avant garde, including Fauvism, Cubism, and Futurism. The show served as a catalyst for American artists towards independence and their own artistic language [14].

The building's role as a catalyst has continued since this impressive beginning. In the last sixteen years the week long Armory Show, with support from the city since 2009, has become America's leading fine art fair devoted to the most important art of the 20th and 21st centuries, housing an international institution, bringing artists, galleries, collectors, critics and curators from all over the world to New York every March. It celebrates the city's artistic communities, promoting a different neighbourhood each day with special receptions, open studios, art tours, museum discounts, performances, panels, and artist discussions. Armory Arts Week attracts not only residents of New York City and the Tri-State area but visitors from all over the world. According to a 2007 independent economic impact study, of the 52,000 visitors to The Armory Show, $56 \%(29,000)$ were visitors to New York City; out-of- town visitors included 11,000 from other countries, 5,000 living in the suburbs, and 13,000 from elsewhere in the United States; among all out-of-town visitors, $73 \%$ cited The Armory Show as their primary reason for being in New York City [18].

Another New York Armoury is also a particularly impressive venue for visual and performance art, as well as being an important architectural landmark. Designed by architect Charles Clinton in the Gothic Revival style and dedicated in 1880, it is one of the two remaining armories in the United States to be built and furnished with private funds [19]. It originally served as the headquarters and administrative building for the 7th New York Militia Regiment, known as the Silk Stocking Regiment, a reflection of the disproportionate number of its members who were part of the city's social elite in its lavish design. 
The main facade of the administration building faces Park Avenue between 66th and 67th Streets, with the large vaulted space for the drill hall in the centre of the block. The administration building has provisions for a reception room, a library, veterans' room and staff offices for ten regimental companies. Noted architects such as Stamford White and interior designers of the American Aesthetic Movement such as Louis Comfort Tiffany, Kimbel and Cabus, Alexander Roux, Francis Davis Millet and the Herter Brothers were commissioned to furnish the rooms and company quarters. The interior is rich in ornamental woodwork, marble and stained glass. Tiffany designed the library, Silver Room or "Trophy Room". The masterpiece of the armoury is the Veterans' Room, with hand carved wood panelling and a coffered ceiling in the Viking Revival style. The building was used for the historic live broadcast of the radio play The Fall of the City by Archibald MacLeish in 1937 because of its acoustic properties. It is leased to The Park Avenue Armory Conservancy, a not-for-profit organization dedicated to restoring it and bringing it back to life as a dynamic centre for the visual and performing arts, following a model of artistic uses found in several European and American cities, but not in New York. Its vast drill hall can accommodate very large installations such as Ann Hamilton's multimedia art installation "the event of a thread," in December 2012 [20]. 42 huge swings were suspended from the Armory's elliptical ceiling and tethered to a massive white cloth spanning the arch and rippling over the spectators. The Armoury was declared a National Historic Landmark in 1986 [21].

As in this case, the large unencumbered spaces of former naval buildings offer wonderful arts opportunities. In 2011 the 5000sq metes of Rotterdam's former Submarine Wharf were transformed into a hallucinatory experience by the Berlinbased Scandinavian art duo Elmgreen and Dragset, in collaboration with the Museum Boijmans van Beuningen and the Port of Rotterdam [25]. Istanbul's lofty toplit Ottoman Tophane-I Amire (Admiral's Cannonball Foundry) makes a wonderful art gallery. It has been part of Mimar Sinan University since 1992, complementing the many new arts facilities in Karaköy [26].

\section{$5 \quad$ Music and film}

Portsmouth's dockyard prison is now occupied by the Royal Marines School of Music: jazz and Mozart echo from the cells. A publicly funded conversion is in Turku in Finland, where a twentieth century dockyard on the bank of river Aura was elegantly transformed into a music conservatoire in 1994, the ropery partitioned as practice rooms. The main hall is a glass-walled, 400 -seat recital hall. The complex also includes three smaller halls as well as rehearsal rooms. The complex designed by LPR Architects has won several Finnish and international architect prizes [27]. During Turku's year as Capital of Culture in 2011 the hub was Logomo (logomo.fi), a cavernous former engineering workshop in the heart of the old industrial and shipbuilding area. The huge brick building hosted the major concerts and five year-long exhibitions. Chatham dockyard's chapel is used as a concert venue, theatre and film location. 
Military and naval sites with their grand architectural set pieces, industrial buildings, barracks, cobbles, large internal spaces, warships, and dry docks make ideal historic film locations. A World Heritage site, the Royal Naval College at Greenwich is home to the University of Greenwich and Trinity College of Music. Greenwich appears so often in costume dramas, it is almost a cliché: Bond movies, Sherlock Holmes, The King's Speech and The Iron Lady. Of English dockyards appearing most frequently in films, Chatham wins hands down: Bonds, Sherlock Holmes, Children of Men, The Golden Compass... The first scene of Les Misérables filled a dry dock in Portsmouth, the actors immersed in freezing water hauling on ropes, and Greenwich and Chatham also feature. Chatham is also the setting for Call the Midwife and Foyle's War and, many years earlier, the 'Carry On' style film, Mind Your Stern. Portsmouth has featured in Bonds, Eastenders, Mansfield Park. The Warrior appeared in Oscar and Lucinda, and HMS Victory in countless TV programmes. I was delighted to recognise the slaughterhouse in Royal Clarence Yard Gosport in a film set in Venice, while the Chinese film Flying Swords of Dragon Gate begins with a long swooping CGI reconstruction shot over the Emperor's junks in Lijiang dockyard [28].

Cinemas may also colonise dockyard spaces - contributing new arts-related activity to places where naval use has ceased. WWII damage to the top floor of Boathouse 6 in Portsmouth dockyard enabled the dramatic insertion of the new auditorum by award winning architects McCormack, Jamieson, Pritchard. It has a triple use: by the Ministry of Defence for conferences with foreign navies and contractors; by tourists visiting Action Stations which occupies the lower two floors to see the video about the modern British navy's tasks in the world; and in the evenings the auditorium is used as an arts cinema. For civilians, being in the dockyard at night - and hearing the loud squawking of the bird scarers on HMS Warrior is a surreal experience!

The Steiner Studios in Brooklyn Navy Yard in New York now actually make many films. The Film Studios' vast sound stages opened in 2004 on a 15-acre site. The 310,000 square-foot buildings provide the city with its first Hollywood-style (and scale) production and support facility. Its five towering sound stages are equipped for start-to-finish production of major motion pictures, independent films, television, broadcast commercials and music videos - with space to grow. Steiner Studios offers production equipment and services on-site, including film and television lighting and grip equipment, scenery and props, design and fabrication services and post-production facilities. The Studio's website emphasises the site's "Rich, Historic Back-lot" - both within the yard, the beautiful views of the Manhattan skyline, the East River bridges, and the historic streets of Fort Greene, Clinton Hill and Williamsburg where film crews are frequently at work. A media campus is planned for the neighbouring derelict naval hospital - when funds can be raised [29].

\section{Festival fort and sites of reconciliation}

Perhaps because it offers enclosed sites and good accoustics as well as its strategic, historic and modern symbolic value, the Petrovaridin fortress on the banks of the 
Danube opposite Novi Sad in Serbia comes alive with music and dance each summer, with more than 250,000 visitors over nine days [30]. The fort was built in 1692 by the Austrians and was besieged by the Turks in 1716 [31]. In the 1990s an artist in a casemate studio described to me the terrifying attack of NATO planes on the key bridge across the Danube below. The Exit festival was founded in 2001 as a student movement, fighting for democracy and freedom in Serbia and the Balkans which precipitated political change there. As an international event the festival has won many awards and raises funds for local students to gain new academic experience.

In many places the Berlin Wall has disappeared since it was broken up in 1989, but the Mauerpark in Mitte the scar has acquired not only a reproduction of the wall, watch tower, searchlights and death strip, but also a moving work of art, the eliptical Kapelle der Versöhnung (Chapel of Reconciliation) constructed in rammed earth from the rubble of the site. It was built on the foundation of the 1894 church blown up by GDR border troops in 1985 .

Once the soldiers left Ebrington Barracks in a strategic position on the River Foyle on the front line between warring Protestants and Catholics in Derry/Londonderry in Northern Ireland, strong reconciliation forces including the Foyle Civic Trust sought to transform it into a centre for arts and culture. The site was first designated for military use during the siege of Derry in 1689; the barracks were constructed inside the star fort from 1839 to 1841 . In WWII they were part of H.M.S Ferret, the main naval escort base and Anti-Submarine Training School for allied navies. As H.M.S Sea Eagle the Joint Anti-Submarine School occupied the barracks until 1970, when the site handed back to the British Army and renamed Ebrington Barracks. The land was transferred to the Northern Ireland government in 2002 and two years later the barracks were closed by the Ministry of Defence. One of two scheduled monuments in Derry, the site contains 19 buildings of historical interest. The Peace Bridge, a symbolic link between the two sides was built across the river in 2011. As part of Derry's celebrations as European City of Culture in 2013, the barracks became a cultural hub for the city where the Turner Prize winners were awarded in the art galleries [32]. Despite $£ 2.5$ being spent on the galleries, they were only open for four months. Lex-Urban Regeneration Company, responsible for the Ebrington space, sought the public's views on uses for the spaces. The results were to be available in summer 2014.

\section{Gallery adds cultural value}

The redevelopment of the historic gun wharf on Portsmouth Harbour, an ordnance depot developed over the town's northern fortifications from 1709, played a key part in two services' technical history where innovation was a constant thread. It was used as the navy torpedo and mining school, and redesignated as HMS Vernon from 1920-1986. Conflicting values - in economics, including potential employment regeneration, heritage, and tourism - were aroused by debate about its future. The local civic society, concerned at the lack of any cultural facility in an otherwise commercial redevelopment of housing and leisure shopping proposed the major surviving historic building, the Vulcan, an ordnance 
storehouse dating from 1814 as an art gallery. Major national institutions including the Tate and Imperial War Museum turned the opportunity down, but the Aspex, a local artists' collective seized the chance. Their conversion of the southern ground floor wing, which involved changing the height of the indoor racks once used for storing war material in order to insert offices inside the overall height, won prizes for design from the RIBA and Portsmouth Society. Unfortunately the closure of the footpath access by the surrounding residents has severely affected visitor numbers [28].

\section{Transformation of whole sites: Governor's Island New York and Skeppsholmen Stockholm}

Entire military sites have also undergone transformation to arts and educational activity. The Duke of York barracks in Chelsea London has been converted into the Saatchi Gallery, while Chelsea College of Arts occupies the listed former Milldam Barracks on the river Thames, appropriately, next to Tate Britain. Governors Island, a 172 acre island in the heart of New York Harbour, is only 800 yards from Lower Manhattan, and even closer to Brooklyn. As a military base it was not publicly accessible for almost two centuries - home to the US Army and later the Coast Guard. It has two historic forts, barracks and fine houses set in wooded parkland with unparalleled views of New York, the Statue of Liberty and the harbour. When it was made redundant its location made its potential monetary value immense. But in the most powerful nation on earth a radical vision prevailed. Rather than development of luxury condominiums, in 2003 the federal government sold 150 acres of the island to the people of New York. Governance and funding are jointly shared by the City and State. The historic core of 22 acres was declared a National Monument overseen by the National Park Service. In April 2010, the City of New York assumed responsibility for it and created a new trust, charged with operations, planning and redevelopment to bring it back to life as a new park and public space for the people of New York. Investment in infrastructure and stabilization is on-going to make the Island a destination as well as an education campus, not for profit and commercial facilities. A design competition was held for a new public park on the land to be cleared of all post1960s construction. British firm Wilkinson Eyre - designers of the award winning Mary Rose museum in Portsmouth dockyard - came second, but the landscape firm 'est8' won. Two ferries from Manhattan and Brooklyn, art fairs, fitness trails and art installations bring thousands of people to enjoy the island every year [33].

As well as the Arsenale in Venice, the Nordic countries offer examples of complete transformations of dockyards. While the World Heritage site of Suomenlinna (Sveaborg) is in mixed use, the naval and military island of Skeppsholmen between the centre of Stockholm and Djurgården where the Vasa is housed has been transformed into an island of art, culture and education. Since 1958 the Moderna Muséet (Modern Museum) of twentieth century art has been on the island. In 1990 Rafael Moneo rebuilt the gallery which has works by Dalí, Picasso, Magritte, Max Ernst and Joan Miro, bought by the state 'as a birthday present to the nation'. The Ariktekturmuseet with a large modernist extension of 
1994-97 is an integral part of the museum. The Östasiatiska Muséet, reflecting Sweden's long connections with the East, has been housed since 1963 in Nicodemus Tessin the Younger's late seventeenth century yellow painted ropewalk Tyghuset. The collection from China, Korea, Japan, India and Southeast Asia has few rivals outside Asia. As well as museums and galleries, the island is a key educational campus. A barracks house the graphics and video schools of the Kunsthögskoln - the University College of Fine Arts - which also occupies a large modern building adjacent to the Identurförrådet (storehouse) of 1730 by Johan Eberhard Carlberg, converted in 1898 to a naval barracks. A brick magazine is the studio of Benny Andersson, a member of the former pop group ABBA. The domed Karl Johans Kyrka of 1842 by Fredrick Blom, inspired by the ideals of the Empire style and by the Pantheon in Rome, is used for exhibitions. A youth hostel is housed on land - in a barracks and on water - in the fully rigged af Chapman of 1888 owned by the City of Stockholm since 1949. A brig, the Tre Kronor is moored near Kastellholmen with its offices and workshops ashore in a boathouse of 1699-1702, and another sailing ship, the Shamrock offering sailing courses is also moored there. Traditional boatbuilding is still taught in workshops, and along the shore numerous historic vessels are berthed, including Two Star, a naval ammunition ship built in Karksrona dockyard and in use until 1992. The large torpedo factory now houses a theatre, the FolkKulturecontrum and a photographic museum. The latest addition to the island's facilities is a hotel [34].

\section{Art events}

One-off artistic events and installations can sometimes make you look again at a familiar scene: Felice Varini's Suite de Triangles (2007-2010) used the terrace on top of Sainte Nazaire's German built armoured sealock as a vantage point to highlight the dock infrastructure. In 2009 in Brooklyn Navy Yard New York Lisa Kirk's 'House of Cards' was "a shanty timeshare built from found materials" installed next to an empty, fire-scarred warehouse for a year (timeshares to stay in it were sold several months in advance) and amenities included no plumbing, no running water, a bucket toilet, hammocks in construction fencing, and an oil barrel bonfire. With unlimited access to the Brooklyn Navy Yard the artist documented day-to-day life: busy dry docks and warehouses, buildings gutted and renovated, streets paved, empty buildings, an unused drydock, abandoned cranes, and herds of feral cats. Appropriately, the House of Cards collapsed; no trace remains [28].

Some arts events are even more ephemeral, like Ghost Ship: the 2009 reenactment of the sinking of Henry VIII's flagship, the Mary Rose as a French invasion fleet approached Portsmouth dockyard via the Solent, the channel between Portsmouth and the Isle of Wight. The event was based on the panoramic Cowdray Print painted between 1545 and 1548 for Sir Anthony Browne, Master of the King's Horse. A huge cast assembled on Southsea Common; the ship was burnt rather than drowned [32]. In 2011 actors and singers celebrated the navy diver Commander Crabb, who was based in HMS Vernon (Gunwharf) and vanished under a visiting Soviet warship, in a spectacular aerial ballet. But Gunwharf/Vernon's history as an arsenal, a base for the navy's Special Boat 
Squadron and a research establishment has largely disappeared, along with most of the historic buildings, except for a handful, such as the Vulcan mentioned above, now an art gallery and flats [28].

\section{Conclusion}

These are just a few of the many examples of Art in its many forms which reanimate and regenerate military sites whose primary purpose has ceased. It contributes creatively to the search to find sustainable new uses for these very special sites.

\section{References}

[1] War and the City GJ Ashworth 1991 Routledge London and New York

[2] Healing War Through Art 2014 Exhibition, Centre for Research in Memory, Narrative and Histories University of Brighton UK

[3] Emails from NCPO Fabio Prosdocimi Naval Library Venice Arsenale 6 May 2014 to Celia Clark

[4] http://www.thetis.it/wp/?p=2269\&lang=en accessed 30 May 20143

[5] Richard Owen 23 February 2008 "Nicolas Sarkozy urged to pay for Napoleon's 'vandalism' of golden barge", The Times London

[6] Warren McManus (transl.), History of the Bucentaurs, Gioielleria Dogale, retrieved 2008-02-28, a translation of an extract from G.B. Rubin de Cervin (1985), La flotta di Venezia: Navi e barche della Serenissima [The Venetian Fleet: Ships and Boats of the Venetian Republic], Milan: Automobilia, ISBN 88-85058-63-9

[7] Malcolm Moore 23 February 2008 (online version updated 26 February 2008)), “Golden barge to resurrect Venice's glorious past", The Daily Telegraph: 20

[8] http://www.hellovenezia.com/index.php?option=com_content\&view=artic le\&id=2185\&Itemi $\mathrm{d}=313$ \&lang=en accessed 30 April 2014

[9] http://www.labiennale.org/en/venues/arsenale.html?back=true accessed 30 April 2014

[10] www.tourism-overwhelms-vanishing-venice.it

[11] Nicholas Serota Times Magazine 17 January 2004

[12] Whitney Joiner, "Postcard: Marfa. A far-flung Texas town stars in two of this year's Oscar-nominated films. Yet a proposed truck route could end its precious seclusion. The battle to stay off the beaten path", TIME 171.8 (February 25, 2008): 6

[13] Fort D. A. Russell National Historic Landmark summary listing. National Park Service. Retrieved 2006-12-14.

[14] "Securing a Space: The 69th Regiment Armory". 1913 Armory Show: the Story in Primary Sources Archives of American Art, Smithsonian Institution. Retrieved 1 February 2013 
[15] Catalogue of International Exhibition of Modern Art, at the Armory of the Sixty-Ninth Infantry, Feb. 15 to Mar. 15, 1913. Association of American Painters and Sculptors, 1913

[16] Walt Kuhn. The Story of the Armory Show. New York, 1938

[17] Milton W. Brown. The Story of the Armory Show. Joseph H. Hirshhorn Foundation, distributed by New York Graphic Society, 1963 republished by Abbeville Press, 1988

[18] http://www.thearmoryshow.com/armory_arts_week/about.html

[19] "Fortress Under Fire". The American Legion Magazine. May 2007. Retrieved 2008-04-05.[dead link]

[20] http://www.denverpost.com/ci_22288730/art-and-active-audienceparticipatory-art-changes-audience

[21] http://www.armoryonpark.org/programs_events/detail/ann_hamilton

[22] "National Register Information System". National Register of Historic Places. National Park Service 2007-01-23

[23] Seventh Regiment Armory. National Historic Landmark summary listing. National Park Service. Retrieved 2007-09-19

[24] Seventh Regiment Armory PDF (214 KB) National Register of Historic Places Inventory-Nomination, undated, by Carolyn Pitts

[25] http://www.boijmans.nl/en/10/press/pressitem/239

[26] http://www.msgsu.edu.tr/msu/pages/tophane-i_amire_k_s_m.aspx

[27] http://www.finnisharchitecture.fi/architects/architect?id $=21460795$

[28] Celia Clark 2014 'Dockyards in Art; Art in Dockyards' Transactions of the Naval Dockyards Society 9 pp. 35-60

[29] www.steinerstudios

[30] "Exit wins Best Major Festival at European Festival Awards". http://www.exitfest.org/en/news/exit-wins-best-major-festival-europeanfestival-awards Retrieved 16 January 2014

[31] Petrovaradin, Enciklopedija Novog Sada, knjiga 20, Novi Sad, 2002

[32] http://www.discovernorthernireland.com/Ebrington-Barracks-HeritageTrail-Londonderry-Derry-P20870; http://www.cityofculture2013.com /venues/ebrington/

[33] www.govisland.com

[34] Celia Clark 2002 “"White Holes”: Decision-Making in Disposal of Ministry of Defence Heritage sites' PhD thesis University of Portsmouth 